\title{
ДЕЯКІ ПРОПОЗИЦІЇ ЩОДО ЗАБЕЗПЕЧЕННЯ ТРАНСПОРТНОЇ БЕЗПЕКИ УКРАЇНИ
}

\section{Фердман Г. П.}

\section{ВСТУП}

Рівень розвитку транспортної системи держави - одна 3 найважливіших ознак ії̈ технологічного прогресу й цивілізованості. Потреба у високорозвиненій транспортній системі ще більше підсилюється за інтеграції в європейську й світову економіку, транспортна система стає базисом для ефективного входження України у світове співтовариство й заняття в ньому місця, що відповідає рівню високорозвиненої держави.

Становлення України як незалежної держави, послідовне проведення виважених реформ i розвиток зовнішніх зв'язків держави чимало залежать від іiї транспортно-географічного положення i ефективної, налагодженої транспортної системи. Транспортний фактор посідає найважливіше місце в теорії регіональної економіки, міжнародної економіки і теорії зовнішньої торгівлі. У зв'язку з цим рівень розвитку та безпеки транспортної системи держави є однією з найважливіших ознак її технологічного прогресу і цивілізованості.

В умовах глобалізації процесів світового розвитку, міжнародних політичних та економічних відносин, які формують нові загрози та ризики для розвитку особистості, суспільства та держави, Україна як гарант добробуту національного розвитку натепер переходить до нової державної політики в галузі національної транспортної безпеки. При цьому реалізація визначеної державної системи правових, економічних, організаційних та інших заходів у сфері транспортної безпеки відповідним загрозам є однією з обов'язкових умов забезпечення національних інтересів та національної безпеки.

3 огляду на необхідність інтеграції в європейське та світове співтовариство Україна приречена приділяти питанням транспортної безпеки пильну увагу. Крім цього, слід зауважити, що Україна має найвищий транзитний рейтинг у Європі, відповідно, вона може отримувати від транзиту і надання інших видів 
транспортних послуг значний прибуток за умови побудови надійної системи транспортної безпеки, шо також зумовлює важливість питань транспортної безпеки для України.

Натепер розвиток інфраструктури, сервісного обслуговування, а також загального економічного технічного стану та безпеки транспортної галузі нашої країни перебуває ще на досить низькому рівні. Внаслідок недосконалості нормативно-правової бази, недостатніх інвестицій у транспортно-дорожній комплекс збільшується зношеність технічних засобів, погіршується їх структура, не дотримується належна безпека руху, зростає негативний вплив діяльності транспорту на навколишнє природне середовище та здоров'я людини. Це призводить до витіснення українських перевізників 3 міжнародних ринків транспортних послуг, особливо в умовах жорсткої конкуренції, знижує якість обслуговування вітчизняних підприємств i населення, створює реальну загрозу економічній безпеці держави.

Усвідомлюючи велике значення транспорту для України, значну увагу необхідно приділяти саме транспортній безпеці. Забезпечення належного рівня транспортної безпеки є одним з основних завдань сучасної держави. Питанням забезпечення транспортної безпеки в Україні поки що приділяється не досить уваги. Так, натепер не прийняті основні нормативні документи у вищезазначеній сфері: стратегія та концепція транспортної безпеки, закон про транспортну безпеку, а заходи, що вживаються, як правило, відрізняються невисокою ефективністю. У розвинених країнах світу питанням безпеки, зокрема транспортної, приділяють велику увагу, що зумовлено величезним значенням транспорту для будь-якої сучасної країни.

\section{1. Усвідомлення інститутами державної влади та громадськістю ролі та місця транспортної безпеки в забезпеченні національних інтересів України}

Проблеми транспортної безпеки останніми роками стали ще гострішими, оскільки транспорт фактично перетворився на одну 3 найризикованіших сфер життєдіяльності, в якій, на жаль, регулярно гинуть люди. Так, згідно зі статистичними даними за 2019 рік, на автошляхах України сталося 2829 дорожньо-транспортних пригод за участю автомобільного транспорту, що надає послуги 3 перевезення пасажирів та небезпечних вантажів, в яких 184 особи загинули та 1588 отримали травми. 
У дорожніх пригодах постраждали 18446 осіб (в 2018 році за такий самий період - 17319 ), що на 6,5\% більше, ніж минулого року.

За інформацію, яка надходила до Укртрансбезпеки, у 2019 році на залізничному транспорті України сталось 1202 транспортні події, 3 них:

705 аварій, в яких 354 особи загинули та 232 отримали травми, 3 них:

1) 577 аварій зі сторонніми особами, завдані рухомим складом залізничного транспорту, в яких 354 особи загинули та 232 отримали травми;

2) 128 аварій за участю залізничного транспорту без постраждалих;

3) 473 інциденти без постраждалих;

4) 24 пожежі.

Протягом 2019 року на залізничних переїздах Укрзалізниці сталось 65 дорожньо-транспортних пригод, в яких 11 осіб загинули та 20 отримали травми. Також за 2019 рік сталось 14 пожеж на автомобільному транспорті загального користування без загиблих та травмованих ${ }^{1}$.

Отже, забезпечення транспортної безпеки полягає в забезпеченні права особи на безпеку в широкому розумінні (захист життя, здоров'я, загалом конституційних прав громадян). Пріоритетним напрямом у цій сфері $є$ запобігання реальним та потенційним загрозам виникнення аварій i катастроф на транспорті та їх наслідкам.

Поняття транспортної безпеки носить системний характер, тому визначає необхідність комплексного, системного вирішення проблем, наявних у цій сфері.

Транспортна безпека $\epsilon$ складником національної безпеки i полягає у запобіганні аваріям та інцидентам на транспорті. 3 огляду на пріоритетність прав i свобод людини така діяльність здійснюється шляхом створення системи раціональної превентивної безпеки 3 метою максимально можливого, економічно обгрунтованого зменшення ймовірності виникнення транспортних

${ }^{1}$ Публічний звіт Голови Державної служби України з безпеки на транспорті Олександра Погорілого за 2019 рік. С. 12, 14, 15. URL: https://www.kmu.gov.ua/ storage/app/sites/1/17-civik-2018/zvit_2019/zvit-2019-ukrtransbezpeka.pdf (дата звернення: 13.03.2020). 
аварій і мінімізації ї наслідків. Під забезпеченням транспортної безпеки слід розуміти соціальний процес діяльності відповідних суб' єктів суспільних відносин із запобігання аваріям та інцидентам на транспорті ${ }^{2}$.

Питання забезпечення транспортної безпеки для України має особливе значення. Насамперед це можна пов'язати з розмірами території та геополітичним розташуванням нашої країни, 3 політичним і соціально-економічним курсами, спрямованими на подальше зміцнення суверенітету. Однак на тлі зростаючих показників аварійності, травматизму, збитків, зносу технічних засобів вихід української транспортної галузі на шлях сталого розвитку із забезпеченням комплексної безпеки вельми ускладнений ${ }^{3}$.

Рівень безпеки перевезень, обсяг споживання енергії та вплив на навколишне природне середовище в Україні не відповідають сучасним вимогам. Протягом останніх десятиліть у світі спостерігається стрімке збільшення кількості транспортних засобів та підвищення інтенсивності руху, що призводить до збільшення кількості транспортних подій та їх негативних наслідків ${ }^{4}$.

Саме тому першочерговим, нагальним завданням $є$ досягнення адекватного розуміння інститутами державної влади та громадськістю ролі та місця транспортної безпеки в забезпеченні національних інтересів України. Про нерозуміння натепер цієї проблеми і 3 боку державних органів, і 3 боку громадськості свідчать такі факти:

1. Законодавчі та інші нормативно-правові документи рясніють суперечностями, розбіжностями, зяючими пробілами.

2. Незадовільне фінансове покриття витрат, пов'язаних 3 транспортною безпекою. В умовах, коли теракти і диверсії на транспорті за допомогою транспортних засобів прийняли загрозливий для суспільства характер, а аварії в транспортному комплексі через знос основних фондів стали по суті звичайним

2 В. Бесчастний, Собакарь А. Державна політика транспортної безпеки України: актуальні питання реалізації. Віче. 2010. № 4. C. 2. URL: http://nbuv.gov.ua/UJRN/viche_2010_4_2. (дата звернення: 07.03.2020).

3 Бурдіна М.Ю., Буркіна Н.В. Аналіз стану транспортної безпеки України. C. 162. URL: file://C:/Users/\%D0\%A4\%D0\%B2\%D1\%8C\%D1\%88/ Downloads/6185-12420-1-SM\%20(7).pdf (дата звернення: 08.03.2020).

${ }^{4}$ Національна транспортна стратегія України на період до 2030 року. URL: https://zakon.rada.gov.ua/laws/show/430-2018-p (дата звернення: 09.03.2020). 
явищем, на потреби забезпечення транспортної безпеки 3 держбюджету виділяються явно недостатні суми, які в десятки, а часом i в сотні разів менші коштів, що виділяються на вищезазначені цілі розвиненими державами, наприклад США, Канадою, низкою європейських країн.

3. Практично не залучені до зміцнення транспортної безпеки активні учасники ринку комерційних перевезень, ліцензовані суб'єкти транспортної діяльності країни.

4. Система транспортної безпеки фактично відсутня 3 причини відсутності самої системи та фактичної відсутності антитерористичних технічних засобів як її основного складника.

5. Не проявляють серйозної заклопотаності 3 приводу стану транспортної безпеки громадські інститути. Інтерес до цієї проблеми систематично актуалізується переважно у зв'язку 3 черговим терористичним актом або іншою надзвичайною подією на транспорті. При цьому, як правило, активність виявляється все частіше у формі спроб осіб, безпосередньо постраждалих у результаті аварії (диверсії, теракту), пред'явити державі позов з приводу відшкодування понесеного ними матеріального і морального збитку. Між тим досвід США, Канади і низки європейських країн говорить про те, що турбота про зміцнення транспортної безпеки перебуває в центрі уваги не тільки держави. Цією проблемою вкрай стурбовані й беруть активну участь у іiі вирішенні громадські організації. Крім того, навіть добре налагоджена система транспортної безпеки не може ефективно функціонувати без широкої опори на розуміння і підтримку всіх структур громадянського суспільства.

Нагальна необхідність широкого позиціонування проблеми транспортної безпеки в державі та суспільстві очевидна. Без досягнення адекватного уявлення органами державної влади та громадськістю ролі і місця транспортної безпеки в забезпеченні національних інтересів України, що змінилися, неможливо досягти і iii якісно нового стану. Вирішення цього завдання вимагає в тому числі широкої роз'яснювальної роботи у вітчизняних та закордонних засобах масової інформації (включаючи Інтернет). До цієї роботи мають бути залучені i наукова громадськість, і представники всіх гілок державної влади, i керівники транспортних компаній, всі активні учасники ринку комерційних перевезень. Вирішення цієї проблеми має бути вбудоване в більш широкий контекст завдань формування зовнішньополітичного 
іміджу України, активно брати участь у боротьбі світового співтовариства проти міжнародного тероризму. Вирішення зазначеного вище завдання і $є$ тією ланкою в загальному ланцюзі зміцнення транспортної безпеки, вхопившись за яку можливо витягнути весь ланцюг на належний рівень. Істотне збільшення цільового фінансування вирішення проблем транспортної безпеки необхідна умова якісного підвищення рівня транспортної безпеки України i приведення його у відповідність до міжнародних стандартів. Особливу роль у вирішенні цього завдання, його фінансового забезпечення мають зіграти громадські організації, комерційні структури 3 числа значних учасників ринку транспортних послуг, страхові компанії та інші комерційні підприємства - споживачі транспортних послуг, у тому числі закордонні, які мають тісні експортно-імпортні відносини 3 Україною.

Пошук i акумулювання позабюджетних коштів на потреби транспортної безпеки - одна 3 необхідних умов вирішення вищезазначеної проблеми. Негайна розробка та вдосконалення нормативно-правових основ транспортної безпеки, приведення іiї у відповідність до міжнародних вимог зумовлено тією обставиною, що наявний розрив між ними може стати серйозним стримуючим фактором для розвитку України як учасника міжнародних транспортних перевезень.

6. Необхідно на законодавчому рівні визначити місце транспорту в сукупності об'єктів, що становлять підвищену небезпеку і потребують особливої системи антитерористичного захисту, а також вирішити питання про нормативно-правову регламентацію забезпечення безпеки підземних споруд.

7. Статус України як активного учасника міжнародного співробітництва у сфері забезпечення безпеки на транспорті вимагає від неї нарощування зусиль не лише в реалізації схвалених міжнародним співтовариством заходів 3 протидії тероризму і підвищенню безпеки на транспорті, а й більш чіткому позиціонуванню своїх інтересів та ініціатив у міжнародних організаціях - 3 авіаційної безпеки (IКАО), морської безпеки (Конвенція СОЛАС-74) та ін.

8. Необхідна концентрація та вдосконалення взаємодії всіх органів виконавчої влади, що відповідають за транспортну безпеку. Відповідно до завдань та функціональних обов'язків правоохоронних органів, спецслужб і контролюючих служб мають 306 
бути більш чітко визначені на законодавчому рівні їх роль, місце, відповідальність, розподіл повноважень та взаємодія як учасників процесу забезпечення транспортної безпеки.

\section{2. Необхідність реформування транспортної безпеки України}

Транспортна безпека характеризує національний транспортний комплекс та його складові частини з точки зору:

-захищеності від актів незаконного втручання в його функціонування;

-захищеності транспортних об'єктів та транспортної інфраструктури від диверсійно-терористичних дій;

- здатності до прогресивного розвитку галузі, яка відповідає економічним та геополітичним інтересам держави;

- рівня інтегрування до світової транспортної системи.

Ситуація, яка склалась в Україні, вказує на зростаючий розрив між рівнем міжнародних вимог та наявним рівнем системи забезпечення безпеки транспортного комплексу. Такий факт найближчим часом може стати значним стримуючим фактором розвитку України як учасника міжнародних транспортних перевезень. Саме тому для України, кожного іiі регіону стійка робота транспортної інфраструктури є однією з основних складових частин національної безпеки держави.

Стає зрозумілою необхідність реформування системи превентивних заходів забезпечення транспортної безпеки в Україні. Розпорядженням Кабінету Міністрів України від 30.05.2018 № 430-p «Про схвалення Національної транспортної стратегії України на період до 2030 року» визначено загальні проблеми, які потребують розв'язання, але відсутній керівний документ щодо транспортної безпеки України. Тому, на нашу думку, до числа основних проблем, вирішення яких має бути забезпечено насамперед, можливо віднести такі:

- приведення наявної законодавчої бази, яка не в повному обсязі відповідає вимогам, які пред'являються міжнародними організаціями в галузі забезпечення транспортної безпеки, у відповідність до міжнародної (європейської);

- розробка єдиних цільових підходів із забезпечення транспортної безпеки, які відповідають міжнародним вимогам, для захисту діяльності транспортного комплексу від терористичних актів та незаконного втручання; 
-чітке визначення джерел фінансування програм безпеки транспортних підприємств, які несуть основне навантаження щодо ресурсного забезпечення системи превентивних заходів безпеки.

На думку О. Сапронова, яка викладена у науковій статті «Основні напрями забезпечення транспортної безпеки України» серед основних причин низького рівня транспортної безпеки в Україні можна виділити:

- відсутність єдиної політики забезпечення транспортної безпеки в країні;

- недосконалість вітчизняного законодавства у сфері транспортної безпеки та відсутність основних нормативних документів для регулювання суспільних відносин у цій сфері: закону, концепції, стратегії та програми;

- неузгодженість і несистемний характер заходів і зусиль органів державної влади з підвищення рівня транспортної безпеки;

-низький рівень правосвідомості та дисципліни працівників і користувачів сфери транспорту;

-незадовільний технічний стан транспортних засобів, транспортних комунікацій та об'єктів, великий обсяг застарілих транспортних засобів і споруд в експлуатації на території України;

- вибухоподібне зростання кількості автотранспорту в країні на фоні відставання розвитку дорожньої інфраструктури;

-незадовільне фінансування заходів із підвищення рівня транспортної безпеки;

- низький рівень підготовки осіб, які впливають на стан транспортної безпеки, зокрема державних службовців у цій сфері, водіїв транспортних засобів та інших працівників транспортної сфери тощо 5 .

На нашу думку, до вищезазначених основних причин низького рівня транспортної безпеки в Україні необхідно також віднести:

-недосконалість системи управління транспортною безпекою;

-відсутність взаємодії між суб'єктами забезпечення транспортної безпеки на різних видах транспорту;

5 Сапронов О. Основні напрями забезпечення транспортної безпеки України. Вісник Національної академії державного управління. С. 89-90. URL: http://visnyk.academy.gov.ua/wp-content/uploads/2013/11/2009-4-14 (дата звернення: 04.03.2020). 
-відсутність єдиного координаційного органу управління транспортною безпекою;

-недосконалість систем моніторингу дорожньо-транспортних пригод, їх статистики, управління ризиками та швидкого реагування на них.

Разом із тим у самій транспортній системі $є$ низка основних невирішених системних проблем:

-відсутня необхідна комплексність в управлінні розвитком i функціонуванням транспортної системи (у період реформ транспорт фактично не розглядався як єдиний об’ єкт державного управління);

-на транспорті не завершені структурні перетворення (присутність держави в сфері транспортного бізнесу й державне регулювання окремих видів транспортної діяльності надлишкові. Не завершене створення правової бази транспорту, адекватної ринковим умовам);

-посилення нерівномірності у використанні виробничих потужностей діючих інфраструктурних об'єктів (зростання об'ємних показників транспортного сектору привело до виникнення низки проблем (дисбалансів) у розвитку транспортної інфраструктури й основних фондів загалом, які, як показує досвід закордонних країн, будуть збільшуватися в міру економічного росту);

-невідповідність темпів розвитку автомобільних доріг темпам автомобілізації країни й соціально-економічних потреб держави й населення;

-у всіх галузях транспортного комплексу намітилися стійкі тенденції старіння основних фондів i ïx неефективного використання (основні фонди всіх видів транспорту обновляються недостатніми темпами, їхнє зношування досягло в цей час майже $80 \%$ і продовжує наростати. При цьому фінансово-економічні механізми, у тому числі ті, які забезпечують відтворення основних фондів і інновації, не досить ефективні й не повною мірою адаптовані до особливостей транспортної галузі);

-наявні значні регіональні невідповідності в розвитку транспортної мережі;

- недостатній технологічний рівень транспортних систем.

Суб'єкти забезпечення транспортної безпеки 3 метою ефективного планування та реалізації заходів транспортної безпеки налагоджують між собою взаємодію з питань: 
a) взаємного інформування про загрозу та виникнення актів незаконного втручання;

б) надання допомоги суб'єктами забезпечення транспортної безпеки один одному у разі загрози та виникнення актів незаконного втручання.

Суб'єкти забезпечення транспортної безпеки, які розміщують на своїх об'єктах або території (акваторії, повітряному або підземному просторі, внутрішніх водних шляхах) об'єкти забезпечення транспортної безпеки інших суб'єктів, відповідають за забезпечення транспортної безпеки на цих об'єктах, якщо інше не передбачено укладеними договорами між цими суб'єктами.

Об'єкти забезпечення транспортної безпеки можуть знаходитись на об'єктах або території (акваторії, повітряному або підземному просторі, внутрішніх водних шляхах) інших суб'єктів забезпечення транспортної безпеки. У цьому разі суб'єктами забезпечення транспортної безпеки, яким ці об'єкти належать, обов'язково забезпечується виконання всіх вимог щодо транспортної безпеки суб'єктів, на території яких вони знаходяться, якщо інше не передбачено укладеними договорами між цими суб'єктами.

Здійснення заходів щодо захисту життя і здоров'я пасажирів та осіб, які перебувають на об'єкті забезпечення транспортної безпеки, а також надання їм допомоги під час загрози або виникнення актів незаконного втручання здійснюється насамперед суб'єктом забезпечення транспортної безпеки, якому належить цей об'єкт.

У разі ускладнення обстановки та неможливості суб'єктом забезпечення транспортної безпеки своїми формуваннями виконувати заходи щодо забезпечення транспортної безпеки він звертається до МВС, центрального органу виконавчої влади у сфері транспорту, дорожнього господарства, надання послуг поштового зв'язку та інфраструктури, центрального органу виконавчої влади, який реалізує державну політику у сфері безпеки на наземному, морському та річковому транспорті, а також до інших суб'єктів забезпечення транспортної безпеки, які на договірних умовах надають йому допомогу.

Рішення про надання додаткових формувань приймають суб'єкти забезпечення транспортної безпеки, яким вони належать, на підставі звернень суб'єктів, на території яких виник акт незаконного втручання.

Отже, всі види транспорту забезпечують свою безпеку самостійно не залежно один від одного, для чого існують відповідні 
сили та засоби, керівні документи та відображено взаємодію 3 іншими державними органами та допоміжними органами i службами, але в жодному з них не розкрито взаємодію з іншими видами транспорту та силовими структурами i, як наслідок, вищезазначене не підкріплено відповідними нормативно-правовими актами.

\section{3. Пропозиції щодо підвищення рівня транспортної безпеки України}

Як наслідок вищезазначеного, відсутній єдиний орган управління транспортною безпекою держави, саме тому відсутня єдина загальна координація дій суб'єктів забезпечення транспортної безпеки України. Отже, необхідне вдосконалення взаємодії всіх органів виконавчої влади та відповідних силових структур, які відповідають та беруть участь у забезпеченні транспортної безпеки. Відповідно до завдань та функціональних обов'язків правоохоронних органів, спецслужб та контролюючих служб мають бути більш чітко визначені на законодавчому рівні їх роль, місце та відповідальність як учасників процесу забезпечення транспортної безпеки. Необхідно створити нову єдину нормативно-правову базу ефективного забезпечення транспортної безпеки з урахуванням змін у формі власності, а також підходів у галузі управління. Принципово важливо, щоб до участі у вищезазначеній роботі залучались не лише науковці та експерти, але й представники громадськості, які не проявляють серйозної занепокоєності 3 приводу стану транспортної безпеки.

Не менш важливу роль відіграють також суб'єкти забезпечення безпеки руху на транспорті, від злагоджених дій яких залежить стан аварійності, рівень транспортного обслуговування населення, якість надання транспортних послуг тощо. Аналіз системи й компетенції суб'єктів управління транспортним комплексом України засвідчує, що нинішня система державного управління безпекою на транспорті потребує вдосконалення. Підвищення якості й посилення обгрунтованості рішень неможливі без систем моніторингу транспортних пригод. 3 огляду на це необхідним $€$ створення організаційної структури, яка має інформувати органи державного управління про стан і проблеми забезпечення безпеки на транспорті, вживані заходи та їх ефективність. Найоптимальнішим видається створення єдиного плановорегулювального, науково-методичного, координаційного та 
контрольного центру, наділеного достатніми повноваженнями щодо організації взаємодії всіх органів державної влади України в зазначеній сфері. Ним може стати Міжвідомчий центр забезпечення транспортної безпеки України (рис. 1).

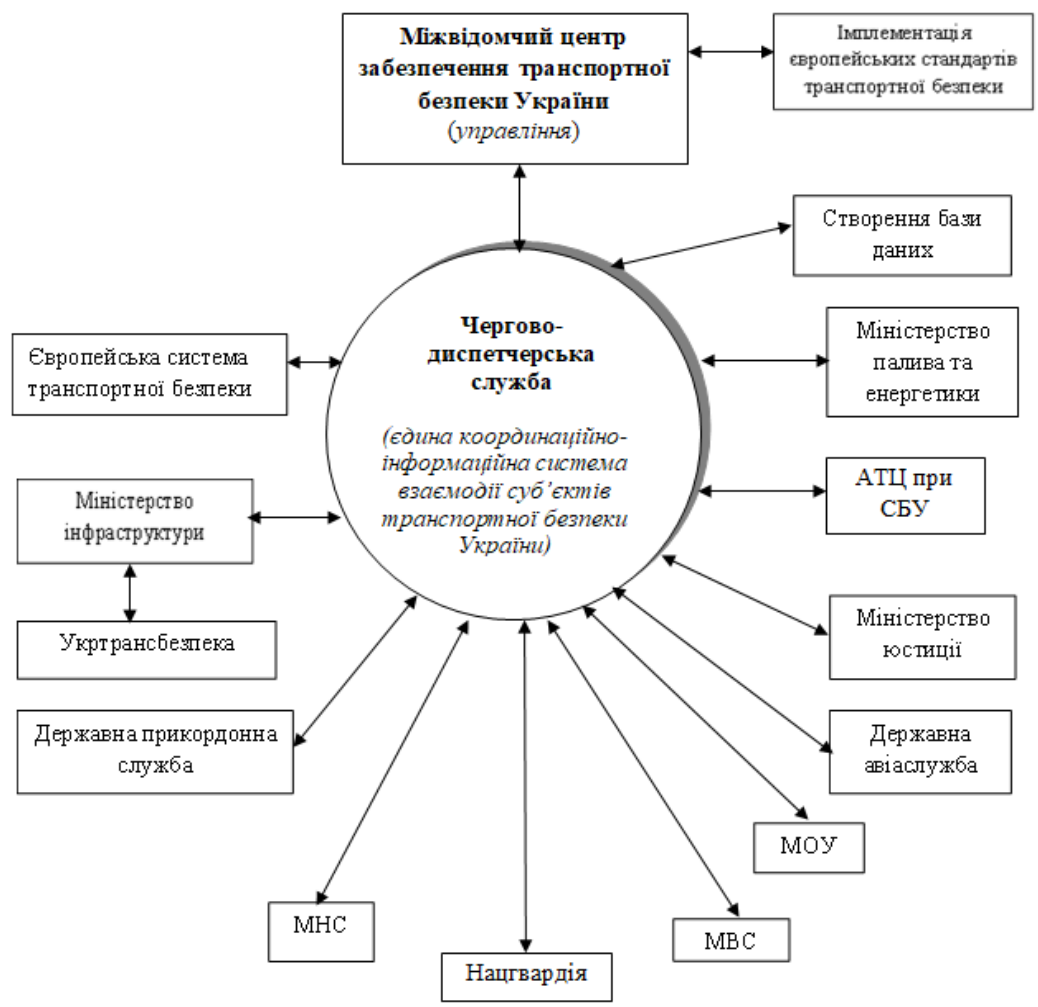

\section{Рис. 1. Концептуальна схема Міжвідомчого центру забезпечення транспортної безпеки України}

Міжвідомчий центр забезпечення транспортної безпеки України мусить складатись 3 :

-управління (надходить уся інформація щодо транспортних пригод та приймаються відповідні рішення, також проводиться відповідна робота 3 імплементації європейських стандартів транспортної безпеки); 
-чергово-диспетчерської служби (приймає всю інформацію про транспортні пригоди та після прийняття рішень управлінням доводить їх до відповідних виконавців).

Чергово-диспетчерська служба має постійний, стійкий прямий i зворотний зв'язок та постійний обмін інформацією з: Міністерством інфраструктури, а через нього з Укртрансбезпекою; Міністерством юстиції; АТЦ при СБУ; МВС; МОУ; МНС; Нацгвардією; Міністерством палива та енергетики; Державною авіаслужбою; Державною прикордонною службою. Крім того, черговодиспетчерська служба постійно створює відповідну базу даних та має постійний обмін інформацією 3 Європейською системою транспортної безпеки.

Створення Міжвідомчого центру забезпечення транспортної безпеки України дасть можливість:

- сконцентрувати весь комплекс управлінських функцій iз забезпечення безпеки на всіх видах транспорту в одному органі та здійснювати централізоване керівництво;

-значно ефективніше вирішувати питання раціональної організації контрольно-наглядової діяльності у вищезазначеній сфері;

-уникнути дублювання функцій і паралельності в діяльності згаданих суб'єктів;

- сприяти подальшому вдосконаленню керівництва і координації діяльності всіх державних органів, правильному розподілу фінансових і матеріально-технічних засобів, які витрачаються на проведення масштабних заходів із забезпечення транспортної безпеки;

- постійно мати інформацію про транспортну безпеку не тільки в Україні, але й за їі межами (особливо на прикордонних дільницях);

-зменшити час на прийняття рішень та їх погодження 3 відповідними посадовими особами;

-зменшити час реакції відповідних структур, які здійснюють ліквідацію транспортних подій і спасіння життя, та силових структур на транспортні події;

-значно підвищити рівень транспортної безпеки в Україні.

Забезпечення транспортної безпеки України має включати:

a) реалізацію оперативних і довгострокових заходів щодо попередження i нейтралізації внутрішніх i зовнішніх загроз транспортній безпеці України; 
б) інвентаризацію міжнародних вимог до забезпечення транспортної безпеки, розробку і реалізацію з урахуванням цих вимог комплексу заходів, спрямованих на якісне підвищення рівня транспортної безпеки України, приведення його у відповідність до міжнародних стандартів безпеки на транспорті.

Вкрай важливою складовою частиною цього комплексу заходів $\epsilon$ розвиток можливостей розвідки $\mathrm{i}$ контррозвідки 3 метою своєчасного виявлення i нейтралізації загроз та визначення їх джерел.

Для забезпечення своєчасного виконання цих підвищених вимог Україні необхідно прийняти низку невідкладних заходів, в іншому разі країна може понести значні економічні та фінансові втрати.

Тому пропонується здійснити реформу системи захисту діяльності транспортного комплексу України від актів незаконного втручання та перш за все його міжнародної частини, визначивши пріоритетами вирішення такі основні задачі:

1. В основу роботи Міністерства інфраструктури України зі створення системи безпеки транспортного комплексу країни необхідно покласти розробку Концепції транспортної безпеки.

2. Розробити законопроєкт «Про транспортну безпеку» з метою уніфікації норм, які регулюють питання транспортної безпеки для різних видів транспорту.

3. Привести українське законодавство у сфері транспортної безпеки у відповідність до міжнародних стандартів та зобов'язань України.

4. Розробити та включити до цільової програми Модернізації транспортної системи України окремий розділ «Безпека транспортної системи України».

5. Передбачити джерела бюджетного та позабюджетного фінансування програм транспортної безпеки України.

6. Оновити парк транспортних засобів та здійснити капітальний ремонт транспортних споруд, що перебувають в аварійному стані, покращити їх експлуатаційні показники.

7. Своєчасно прогнозувати та виявляти зовнішні і внутрішні загрози національній безпеці України у транспортній сфері.

8. Створити Міжвідомчий центр забезпечення транспортної безпеки України - єдину систему управління транспортною безпекою за рахунок реорганізації структурних підрозділів Міністерства інфраструктури України 3 введенням посади заступника Міністра з транспортної безпеки. 
9. Розробити та реалізувати заходи із забезпечення транспортної безпеки України.

10. Розробити оцінку вразливості об’єктів транспортної інфраструктури і транспортних засобів та їх категоризацію.

11. Забезпечити антитерористичну безпеку на транспорті та заходи щодо недопущення незаконного втручання в його роботу.

12. Створити єдину систему транспортного телебачення iз залученням антитерористичних технічних засобів (терміналів з виявлення вибухових та отруйних речовин, зброї та боєприпасів).

13. Створити на державному рівні систему ліцензування організацій та підприємств на предмет їх відповідності вимогам захисту від вищезазначених загроз диверсійно-терористичного характеру.

13. Здійснювати заходи, які спрямовані на недопущення або мінімізацію матеріального і морального збитку від злочинів та надзвичайних подій на транспорті.

14. Проводити постійну роботу 3 нейтралізації негативного впливу транспорту на екологію України, у тому числі шляхом використання новітніх технологій.

15. Продовжити грунтовні наукові дослідження у сфері забезпечення транспортної безпеки України.

Рішення та заходи, які вживаються органами державної влади в галузі зміцнення транспортної безпеки України, мають бути зрозумілі кожному громадянину, носити попереджуючий характер, забезпечувати рівність усіх перед законом і невідворотність відповідальності, мають спиратись на широку підтримку суспільства.

Кожний із затверджених до виконання заходів мусить мати конкретні, виважені параметри, термін виконання, бюджетне фінансування та відповідальних виконавців. Проблеми у сфері транспортної безпеки мають вирішуватись комплексно і системно, оскільки транспортна безпека - системне поняття, що включає в себе окремі самостійні сектори або ж види безпеки, зокрема безпеку людей, вантажу, транспортних засобів та об'єктів транспорту, а також екологічну, економічну, військову, пожежну, санітарну, інформаційну, хімічну, бактеріологічну, радіаційну та інші види безпеки.

Отже, прийняття запропонованих заходів дасть змогу підняти на новий, якісний, конкурентоспроможний рівень систему транспортної безпеки України та гідно увійти до системи транспортної безпеки Свропи. 


\section{ВИСНОВКИ}

Таким чином, 3 урахуванням вищезазначеного можна зробити такі основні висновки:

1. Аналіз сучасних тенденцій і проблем розвитку транспортної інфраструктури й основних фондів вказує на те, що вони мають системний характер i вимагають комплексного підходу до їх вирішення. Прогнозоване зростання попиту на перевезення всіх видів транспорту, з одного боку, і негативні явища в транспортній системі загалом й окремих іiі підгалузях - 3 іншого, створюють загрозу загальноекономічному росту України й окремих іiі регіонів, ослаблення позицій України на світовому ринку транспортних послуг.

2. Стан та проблеми транспортної безпеки, іiі розвитку на сучасному етапі перетворюються на серйозну перешкоду на шляху реалізації національних інтересів та забезпечення як економічної, так і національної безпеки держави як загалом, так і за окремими іiі елементами.

3. Створення Міжвідомчого центру забезпечення транспортної безпеки України дасть можливість стати єдиним плановорегулюючим, науково-методичним, координаційним та контролюючим центром, наділеним достатніми повноваженнями щодо організації взаємодії всіх органів державної влади та силових структур України в сфері транспортної безпеки.

4. Проблеми у сфері транспортної безпеки мають вирішуватись комплексно і системно, оскільки транспортна безпека - системне поняття, що включає в себе окремі самостійні сектори або ж види безпеки, зокрема безпеку людей, вантажу, транспортних засобів та об'єктів транспорту, а також екологічну, економічну, військову, пожежну, санітарну, інформаційну, хімічну, бактеріологічну, радіаційну та інші види безпеки.

5. Інтеграція зусиль науковців, політиків, управлінців у напрямі пошуку принципово нових ідей, політичних та управлінських рішень у контексті осмислення сучасних поглядів на сутність, шляхи, засоби, способи й методи захисту національних інтересів на основі науково обгрунтованих засад державного управління у сфері забезпечення транспортної безпеки залишаються актуальними, а система й компетенції суб'єктів державного управління безпекою на транспорті потребують вдосконалення. 


\section{АНОТАЦІЯ}

Забезпечення належного рівня транспортної безпеки є одним 3 основних завдань сучасної держави. Маючи найвищий транзитний рейтинг у Європі та 3 огляду на необхідність інтеграції в європейське та світове співтовариство, Україна приречена приділяти питанням транспортної безпеки пильну увагу. Проблеми транспортної безпеки останніми роками стали ще гострішими, оскільки транспорт фактично перетворився на одну 3 найризикованіших сфер життєдіяльності, в якій, на жаль, регулярно гинуть люди. Питанням забезпечення транспортної безпеки в Україні поки що приділяється не досить уваги. Саме тому у статті висвітлено усвідомлення інститутами державної влади та громадськістю ролі та місця транспортної безпеки в забезпеченні національних інтересів України, недосконалість взаємодії суб'єктів забезпечення транспортної безпеки, необхідність вдосконалення та реформування транспортної безпеки України згідно 3 європейськими стандартами. 3 урахуванням вищезазначеного надано пропозиції щодо підвищення рівня транспортної безпеки України, що дасть можливість гідно приєднатись до європейської транспортної безпеки.

\section{ЛIТЕРАТУРА}

1. Публічний звіт Голови Державної служби України з безпеки на транспорті Олександра Погорілого за 2019 рік. С. 12, 14, 15. URL: https://www.kmu.gov.ua/storage/app/sites/1/17-civik2018/zvit_2019/zvit-2019-ukrtransbezpeka.pdf (дата звернення: 13.03.2020).

2. Бесчастний В., Собакарь А. Державна політика транспортної безпеки України: актуальні питання реалізації. Віче. 2010. № 4, С. 2. URL: http://nbuv.gov.ua/UJRN/viche_2010_4_2. (дата звернення: 07.03.2020).

3. Бурдіна М.Ю., Буркіна Н.В. Аналіз стану транспортної безпеки України. C. 162. URL: file:///C:/Users/\%D0\%A4\% D0\%B2\%D1\%8C\%D1\%88/Downloads/6185-12420-1-SM\%20(7).pdf (дата звернення: 08.03.2020).

4. Національна транспортна стратегія України на період до 2030 року. URL: https://zakon.rada.gov.ua/laws/show/430-2018-p (дата звернення: 09.03.2020).

5. Сапронов О. Основні напрями забезпечення транспортної безпеки України. Вісник Національної академії державного 
управління. С. 89-90. URL: http://visnyk.academy.gov.ua/wpcontent/uploads/2013/11/2009-4-14. (дата звернення: 04.03.2020).

\section{Information about author: Ferdman G. P.,}

Candidate of Sciences in Public Administration, Senior Researcher, Deputy Chief of the State Oceanarium Research Institute of the Armed Forces of the Naval Forces of the National University "Odessa Naval Academy" for Scientific Work, Scientific Center of the Armed Forces of Ukraine State Institute of Naval Forces of the National University "Odessa Naval Academy" 18, Army Str., Odessa, 65000, Ukraine 